\title{
The Complexity of Zero Anaphora in Chinese Discourse: An Event-related Perspective
}

\author{
Kun Sun \\ kun.sun@uni-tuebingen.de \\ University of Tübingen
}

\begin{abstract}
:
One zero anaphor (henceforth, ZA) in Chinese discourse is not necessarily identified with an antecedent which must be found somewhere as a syntactic constituent in a clause. Most studies claim that the referent of zero anaphor is either co-referential with the next ZA or completely different from the next ZA; however the view is not necessarily reliable. This study considers several types of complex cases where referents of ZA can be extracted from several syntactic positions or that never emerge in the context. The complexity of ZA referents thus far surpasses the explanations offered by the current theories, such as the topic chain, accessibility, or discourse structure. This study proposes two principles: co-referential topic and event integration to interpret what causes the complexity of ZA referents in Chinese discourse. Further, this study figures out a mathematical method (hypergraph) to simulate how Chinese native speakers process complex ZAs. This study therefore is significant to make a deeper understanding of the complexity of zero anaphora in Chinese and expand the vision of anaphora.
\end{abstract}

Key words: the antecedent of zero anaphor; independent phrases; co-referential topic; event integration; hypergraph 


\section{Introduction}

In a broad sense, 'anaphora' can be defined as a linguistic phenomenon in which the interpretation of a linguistic expression (anaphor) depends on the entity denoted by another expression (antecedent) in the same text. In terms of the morpho-syntactic features of antecedents, anaphora can be classified into nominal anaphora, verbal anaphora, adjectival anaphora, adverbial anaphora, and even clausal anaphora. But narrowly, anaphora "is used most commonly in theoretical linguistics to denote any case where two nominal expressions are assigned the same referential value or range" (Wilson \& Keil, 1999: 20).

"The study of the syntactic configurations in which the antecedent-dependent pair may occur, and of the types of semantic relation they may bear to each other, is called anaphora. The most widely studied cases of anaphora in generative grammar are those involving nominal expressions and the pronouns." (Strazny 2005: 49)

Linguists are keen on anaphor-oriented classification and identity-of-reference anaphora, hence they mostly focus on noun anaphora, pronominal anaphora, zero anaphora and co-reference.

For example, in I like Tom. He looks very handsome, 'Tom' is the antecedent of the anaphor 'he'. The case here is a visible anaphor which occurs inter-sententially.

When an anaphor is invisible inter-sententially, the relationship between the anaphor and its antecedent (referent) is called zero anaphora. The Chinese language is distinguished by the abundant use of zero anaphora. Therefore, numerous studies on Chinese zero anaphora attempt to clarify which factors influence the use of zero anaphors (i.e. Li \& Thompson, 1979; Chen, 1986; Tao, 1993; Huang, 2000, etc.), and some of them contribute to methods of recovering the antecedents (referents) of zero anaphors. These studies tacitly acknowledge the precondition that each zero anaphor in Chinese discourse must have its antecedent in the context. For example, in Tom closed the door, ø went down the stairs, ø walked on the street, ø found a large birch tree...”, ' $\varnothing$ ' is a zero anaphor and its antecedent is 'Tom'. Hence, here the three zero anaphors are coreferential: all of them refer to 'he'. However, there are a great many counterexamples to this tacit precondition.

This study investigates whether there is an identified antecedent occurring in discourse for any zero anaphor. It illustrates that the antecedents for some zero anaphors cannot be found in the discourse and that in some cases a zero anaphor has a referent combined by several distinct referents that are in all probability dispersed into different syntactic positions. When the antecedent of ZA cannot be found in discourse or is combined by different syntactic elements dispersed in 
different positions, we call the linguistic phenomenon a complex ZA and this phenomenon has seldom been delineated and analyzed in previous studies.

This study holds that in a sense, every zero anaphor in a text must have its referent but does not necessarily claim an antecedent (another linguistic expression in the same text). Thus, a second important aspect of this study is the probing of the underlying mechanism of complexity for these antecedents (referents). This study therefore is significantly helpful for gaining a deeper understanding of the complexity of zero anaphora and the nature of zero anaphora in Chinese discourse. It should be of interest to those investigating factors influencing the zero anaphora, as well as resolutions for zero pronouns and zero co-reference in discourse processing.

The research is structured as follows: the first part analyzes complex antecedents and (non)ambiguous referents occurring in Chinese discourse, whereas the second part is an exploration of how co-referential topic and event integration influence the making of a complex ZA, as well as a theoretical algorithm to simulate how Chinese natives process a complex ZA. .

\section{A Brief Review of Zero Anaphora in Chinese}

Anaphora is influenced by various factors, such as those addressed by syntax, semantics, pragmatics, discourse, and even non-linguistic factors. Hence linguists can adopt different approaches to study it. Similarly, zero anaphora in Chinese has also been studied from the perspective of these approaches.

\subsection{Chinese Zero Anaphora}

In comparison with and in contrast to English, the Chinese language uses more zero anaphors, quite few pronouns and has a preference for using nominal entities bare in form. Following the western traditions, linguists adopt syntactic, pragmatic and textual approaches to explore Chinese zero anaphora. For example, Huang (1982) studies Chinese zero anaphora (called Empty Categories) intra-sententially in terms of the Pro-Drop Parameter or the Null Subject Parameter from the perspective of generative grammar. Zero anaphora obeys the same pragmatic discourse constraints as the use of pronouns (Chen, 1986; Tao, 1993) and the pragmatic discourse constraints that govern reference management are interpreted by the 'information flow' investigated in depth by Chafe (1994), Du Bois (1980), etc.

Anaphora is commonly used in theoretical linguistics to describe any case where two linguistic expressions are assigned the same referential value or range. Zero anaphora in Chinese 
is naturally considered to be the relationship between two linguistic expressions. Therefore it is reasonable to conclude that every zero anaphor must have its antecedent as a matter of principle. This has been implicitly accepted by all studies concerning Chinese zero anaphora intersententially.

\subsection{Three Approaches to Zero Anaphora in Chinese}

Research methods have classified three operations upon zero anaphora: referent tracing, referential recovery, and referential resolution ${ }^{1}$.

1) Referent tracking. The term is used to treat anaphora as a means to trace co-reference. According to Chen (1986), the use of ZA in Chinese signifies high continuity and negligibility due to low plot saliency or adjunct status. The method of referent tracking is one traditional approach to anaphora, used by Gordon \& Chan(1995), Kintsch \& van Dijk(1978), van Dijk \& Kintsch(1983). A number of studies on Chinese zero anaphora follow this method by integrating pragmatic, discursive or cognitive factors.

Tao $(1993,1996)$ assumes a psycholinguistic or cognitive approach to investigating Chinese zero anaphora, but her method is still that of referent tracing. Tao creates the term 'emergent reference', which means reference tracking in the return-pop pattern. Emergent reference may be explained by a set of cognitive strategies, or it refers to a set of cognitive strategies for language users to process discourse with an abundant use of zero anaphora. Emergent reference includes cue identification, reference construction, and information integration. Essentially, Tao employs cognitive experimental methods to study referent tracing for Chinese ZA.

2) Referential recovery. The method attempts to discover the antecedent for each $Z A$ in Chinese. You (1998) uses topic continuity to discuss the working mechanism of ZA in Chinese discourse, and her approach is the referential-recovery pattern. On basis of Cheng (1988), You proposes three principles to analyze zero anaphora: recency principle, primacy principle, and disjoincy principle. She believes that when the syntactic element is nearest to the anaphora in the consequent clause, the element is likely to become the antecedent for a ZA. Her primacy principle consists of the three sub-principles, but mainly it means that the main element of (sub-)topic continuity has to be more accessible to become the antecedent for the ZA, in comparison with

\footnotetext{
${ }^{1}$ There are in general four major types of reference-tracking systems operating in discourse, of which a given language may resort to one or more: (i) gender systems, (ii) switch-reference systems, (iii) switch-function systems, and (iv) inference systems. Some can be used to study zero anaphora, but some are suitable for anaphora. The four types only are the operations of referencetracking method. In spite of this they are very popular. The three methods mentioned in this study overlap slightly, but they are wholly distinct from each other.
} 
other referential entities for ZA. Her disjoincy principle is explained as follows: "A zero anaphor in a clause refers to a candidate referent which is not present in the same clause and which is not the antecedent of the other anaphora, including pronominal anaphor and zero anaphor, in the same clause." (You, 1998: 222). Actually, although You regards her three principles as "Recovery Rules", the issue is not defined explicitly in her dissertation, and recovery rules are the recovery of the referents of zero anaphors from her theory and examples.

3) Referential resolution. The word "resolution" is used to refer to computing referential relation in computational linguistics. In linguistics, the situation of "resolution" is different from computational linguistics.

Using the term "resolution", Xu (1995) concerns himself with the decoding of anaphora. He divides referring expressions into three types - high, intermediate, and low accessibility markers by borrowing Ariel's accessibility theory. He also creates several new concepts about topic: cotopic, expected topic, and topic stack. Zero anaphora in Chinese thus indicates high accessibility as the current topic, expected topic or salient expected co-topic. Actually, Xu treats anaphora as a decoding system, so his resolution of anaphora is to decode how zero anaphora works through accessibility theory.

In computational linguistics, reference resolution is the task of determining what entities are referring to by what linguistic expression (Jurafsky \& Martin, 2009: 695). There are three key algorithms for pronominal anaphora resolution: the Hobbs algorithm, a Centering algorithm, and a log-linear algorithm. Without involving complicated syntactic parsing, the centering algorithm has achieved the stratification of results. The centering algorithm, or centering theory as it is called in linguistics, is originally designed for solving anaphora resolution, but after modifying its parameters, the model can be used to resolve the connection of antecedent and anaphora in language studies.

The three operations with different terms share the greatest similarity: every zero anaphor has its identified antecedent. Their tasks pursue the same purpose: to find the antecedent of an anaphor and to explain the factors that influence the occurrence of ZA. Their biggest dissimilarity is that they identify different factors in explaining what causes ZA. For example, Chen (1986) resorts to factors such as low plot saliency or adjunct status to explain and predict the occurrence of ZA. You (1998) and Lee (2002) use three principles to do the same task.

\subsection{Identified Explicit Antecedents}

Currently, the antecedent of a ZA can be distributed in various syntactic positions if the ZA 
can be identified with its antecedent. Antecedents of zero anaphors can be roughly classified into five types according to their syntactic behavior (position and function)(Liu 2009):
a) the antecedent as the subject in a clause;
b) the antecedent as part of the subject in a clause;
c) the antecedent as the object of a clause;
d) the antecedent occurring behind ZA;
f) the antecedent as an entity in a pivotal clause;
g) the antecedent as another syntactic constituent in a clause.

Consider the following the examples:

[1] jiù jiùu 1 lái kàn wǒ , $\emptyset_{1}$ dài le fèn $\underline{\text { kăo } \mathbf{y} \overline{\mathbf{a}}_{2},} \quad \emptyset_{2}$ hěn hăo chī 。 Uncle come visit me, (uncle) bring PFV M roast duck, (roast duck) very delicious.

"When my uncle came to visit me, he brought one portion of roast duck which was very delicious."

The antecedent of the first ZA "uncle" is the subject in the first clause, but the antecedent of the second ZA "roast duck" functions in the role of object in the second clause. The second antecedent occurs in the clause with the first ZA, so the antecedent can be seen as an entity in the pivotal clause.

[2] tā jiăo shòu shāng le, Ø $\varnothing_{1}$ bú néng lái tīng jiăng zuò le 。

He feet hurt PFV, (he) not can come attend lecture PFV.

"His feet were injured, so he cannot attend the lecture."

The antecedent of ZA is "he" which is one part of the subject group "his feet" in the previous clause.

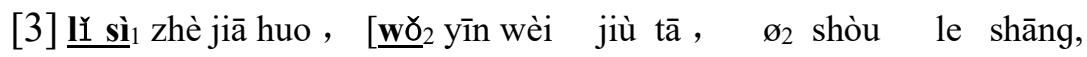
Lisi this M dude, I because save him, (I) receive PFV wound,

$\varnothing_{1}$ jìng rán bù lái kàn wǒ, $\varnothing_{1}$ păo dào niǔ yuē dù jiă qù le,

(Lisi) even NOT-come see me, (Lisi) run-to New York have vacation go PFV,

ai, $\quad \varnothing_{2}$ dăo méi tòu ding, $\quad \varnothing_{2}$ shòu shāng yán zhòng , $\varnothing_{2}$ bú néng xià chuáng ...

Oh, ( I) extremely unluckily, ( I) injured seriously, (I) cannot get up.....

"Lisi, that dude I was wounded in saving, doesn't even come to see me and went to New York for a vacation. Extremely unluckily, I was injured seriously so that I cannot get up...

In this example, the first ZA refers to "I", but the second has the antecedent of "Lisi", and the same to the third zero. The continuous ZA having different referring entities can be judged from the clues provided from the context, and are called switch referents (You 1998; Lee 2003; Tao 1993, 2001). The antecedents in this example also occur in the context.

The three examples share the similarity that the several zero anaphors may have different referents although they are seemingly in a co-referential condition or within a topic chain. But the three cases still follow the precondition that one ZA has its antecedent which must occur as one 
syntactic element in a (contextual) clause. The antecedent of the first zero anaphor in [1] is "uncle" which occurs as a syntactic element of a clause, and the second zero anaphor's antecedent "roast duck" also occurs in a clause even though two zero anaphora have different antecedents. In fact, in the switch-reference pattern, the embedded clause and the return pop, the discussion only focuses on how several consecutive zero anaphors have different antecedents which must be identified and which occur in a certain syntactic position (in quite few cases, an antecedent is invisible momentarily, but it must occur in context).

All these studies have basically reached a consensus: a ZA must be accurately identified with an antecedent which must be present somewhere as a syntactic element. Additionally, they hold that one zero anaphor is co-referential with the next one, otherwise it must be totally different from the next. However, these claims are not all factual. The complexity of a ZA lies far beyond our current knowledge.

\section{Complex Antecedents of Zero Anaphors}

There are several types of ZAs which are quite different from the aforementioned. In some cases, a ZA is partly co-referential with the next, an issue which has never been discussed before. In other cases, the referent of ZA is a combination which is scattered across different syntactic locations, such that this referent seems to be obtained by extracting several syntactic elements. It is also often the case that many ZAs have vague referents.

\subsection{Gradual Accumulation of Referent}

The topic chain in discourse requires all zero forms to be completely co-referential. Chu (1998: 324) offers an inclusive definition of the topic chain: "a topic chain is a set of clauses linked by a topic in the form of ZA (zero anaphora)". However there is one variety in the topic chain with a prominent feature, namely that the antecedents of these co-referential zeros partially overlap and the maximum commonality they share is generally an NP.

Observe the example below:

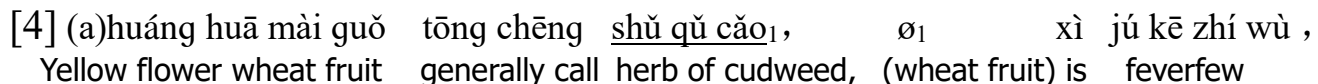

(b) $\varnothing_{1}$ yè̀2 xiăo wēi yuán hù shēng, $\varnothing_{1} \quad \varnothing_{2}$ biăo miàn yǒu bái máo ,

(wheat fruit) leave small slightly round alternate, (wheat fruit leave) surface have white villus,

(c) $\varnothing_{1} \quad$ huāa 3 huáng sè , $\varnothing_{1} \varnothing_{3}$ cù shēng shāo tóu 。

(wheat fruit) flower yellow, (wheat fruit flower) clusters grow top. 
(d) $\varnothing_{1} \quad$ chūn tiān căi nèn yè̀, (wheat fruit) Spring pick up fineleaf,

(e) $\emptyset_{1} \varnothing_{4} \quad$ dăo làn qù zhī , (wheat fruit fineleaf) pound press juice,

(f) Ø hé fẽn zuò gāo , (wheat fruit fineleaf pound press juice) knead into dough make into cake,

(g) $\varnothing \quad$ chēng huáng huā mài guǒ gāo 。 (wheat fruit made into cake) call Yellow flower wheat fruit cake.

[Translation] As feverfew, yellow flower wheat fruit, generally called herb of cudweed, has small slightly round alternate leaves whose surface has white villus, with yellow flowers growing in clusters on the top of branches. After its fine leaves are picked up in spring, they are pounded into pieces and pressed. Afterwards, it is kneaded into dough and finally made into cakes which are called yellow flower wheat fruitcake.

The following graph clearly shows the antecedent of each zero form.

huáng huā mài quǒ tōng chēng shŭ qŭ căo, ( T )

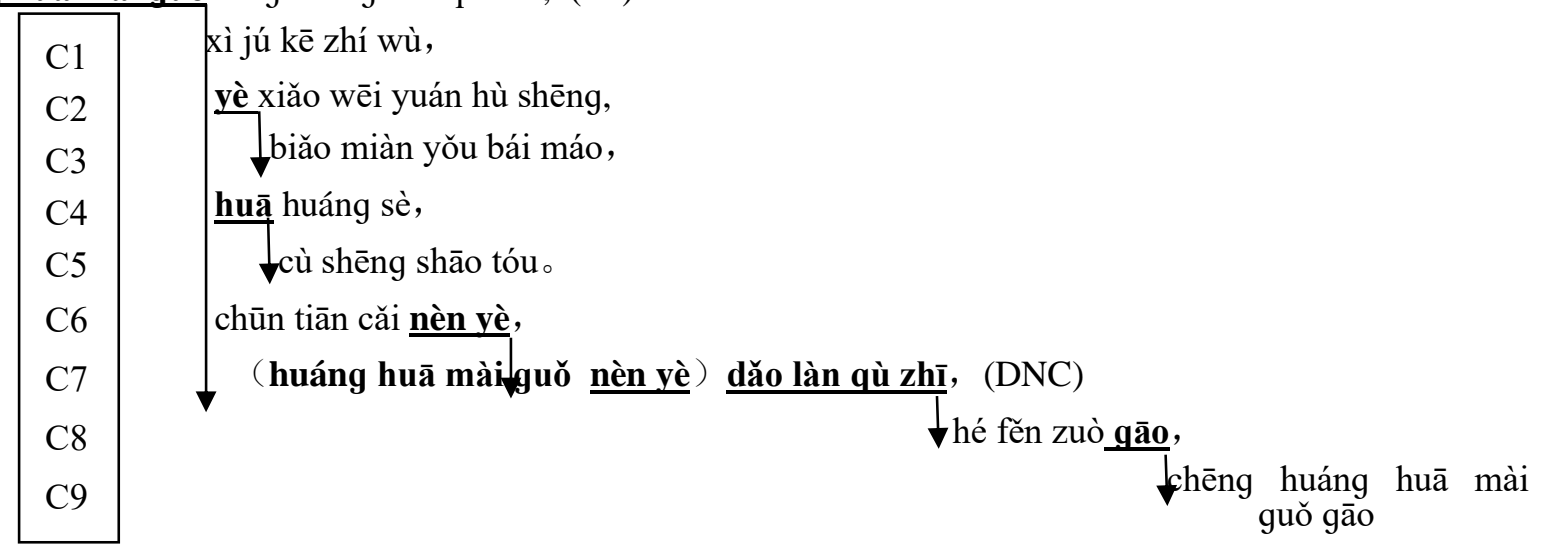

Figure 1: an example of gradual accumulation of referent

The zero forms are not exactly the same, although they seem to be co-referential in this example. $\mathrm{C} 1$ (clause a) and $\mathrm{C} 2$ (clause b) have co-referential zeros, while the zero form in $\mathrm{C} 3$ is decoded by 'yellow flower wheat fruit's fine leaves' which is different from the referent (yellow flower wheat fruit) of the previous two zeros. C7 (clause e) has a zero with the antecedent "yellow flower wheat fruit's fine leaves". By contrast, the zero form in C8 (clause f) referring to "cudweed fine leaf is pounded into pieces and pressed" is the whole content of the adjoining clause. Every zero form from $\mathrm{C} 1-\mathrm{C} 9$, however, has the same constituent, "yellow flower wheat fruit", and this same constituent occurs in each clause. (Sun 2015, 2018, 2019a, 2019b)

Some ZAs in this passage have nominal referents derived from the previous clauses through gradual accumulation, but sometimes their antecedents are not always nominal, for example, the 
antecedent of zero in C8(clause f) contains verbs "pound press juice". The partly co-referential zeros in this example also demonstrate that they include non-nominal constituents. No matter how different those zeros are, they invariably share the nominal constituent.

\subsection{Collective Referent}

The referent of a ZA does not necessarily occur in a certain syntactic position. Consider the following example.

[5]

yì tiān, $\varnothing_{1}$ chèn tā xí zăo, wǒn 1 biàn qù jiăn chá tā de yī fu ,

one day, (I)take advantage of him bathe, I at once go search his DE clothes.

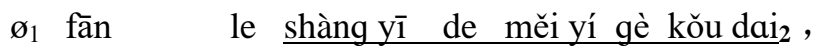

( I ) turn over PFV top clothes DE every M pocket,

$\emptyset_{1}$ yòu qù fān kù zi de kǒu dai 3 ,

( I )further go turn over trousers DE pocket,

jié guǒ $\boldsymbol{\emptyset}_{2 \& 3}$ jì wú xiàn jīn, $\boldsymbol{\sigma}_{2 \& 3}$ yòu wú cún zhé 。

result both not have cash, and not have account book.

[Translation] One day when he was taking a bath, I searched his clothes, [I] went through all the pockets of his shirts and jackets and through his trousers pockets, it turned out that there was neither cash, nor a bank-account book. (Liu and Li, 1994: 156, from Chu1998:335 )

In this passage, the former three ZAs share the same referential entity "I" which is mentioned in the second clause, but the latter ZA shares the referent with two ZAs for two items (every pocket of top clothes, trousers' pocket) which are mentioned in two different places.

The following example will show a more complicated situation:

[6](a) ān hū sheng......

Anhui Province.......

(b) Ø1 lào zāi zé yǐ huái hé liú yù jiào duō, water-logging disaster CONJ Huai River area more,

(c) Ø્ zhǔ yào chū xiàn zài $7-8 y u e ̀$, mainly appear between July- August,

(d) $\varnothing_{3}$ cì wéi chăng jiāng liú yù , secondly Yang-tze River area,

(e) $\varnothing_{4}$ duō chū xiàn zài 6-7 yuè 。 mostly appear between June-July.

The second zero anaphor $\left(\varnothing_{2}\right)$ in $(c)$ should be recovered as "ān huī sheng/ lào zāi/ zài /huái hé liú yù" (Anhui Province water-logging disaster in the Huai River area). This antecedent is obtained through extracting one NP (Anhui Province) in the prior clause and another two NPs located in different syntactic positions of (b) (water-logging/ Huai River area), as well as by adding one preposition "zài"(in), shown in the graph below. 


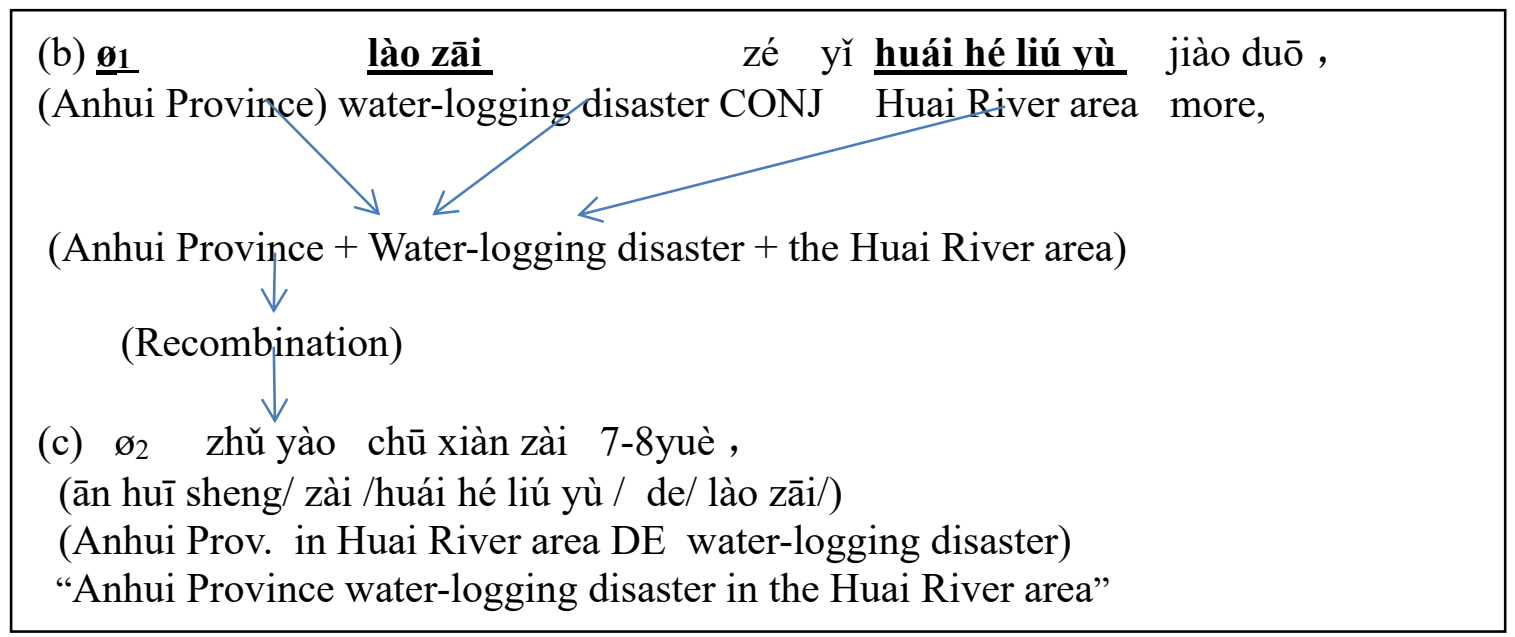

Figure 2: the mixture of a zero anaphor

Likewise, the fourth zero anaphor $\left(\varnothing_{4}\right)$ has a complicated referent "Anhui Province/ water-logging / zài / Yang-tze River area" (Anhui Province water-logging disaster in the Yang-tze River area) which is procured through the extraction of three constituents and the addition of one preposition. In this case, an antecedent of a ZA may be a combination derived from different syntactic constituents, even from different clauses.

The collective referent is different from an abstract anaphor which denotes that an anaphor has an antecedent referring to an abstract object like an event or a fact, for example. (Dipper et al., 2011) Each fall, penguins migrate to Fiji. It happens just before the eggs hatch.

In this example, the pronoun "it" is seen as an abstract anaphor referring to the previous event, according to Dipper et al. The collective and generalizing reference of the noun "penguins" is not pronominally resumed, since "it" is the pronoun for just one partial event described in the preceding clause, whereas the whole of the second zero anaphor in [6] is described in three clauses. Hence this case of zero anaphor is much more complex than that of abstract anaphora.

\subsection{Implicit Referent}

The referent of ZA can be extracted from different syntactic constituents through complex cognitive processes, but in some situations there is no way to discover any element of this referent mentioned in context, even if the ZA can be recovered. Consider the following example:

[7] (a)(tā men )zhuā le shí jǐ jì tāng yào ,

(they) catch PFV dozens of dose tisane,

(b) (jīn shān) chī le guǒ rán bú háng ,

(Jin Shan) take PFV as expected invalid,

(c) ( tā men ) biàn zhī hăo dān yī (gěi tā ) chī fàn chī shuǐ ,

(they) then have to singly (give him) eat food drink water,

(d) (jīn shān ) shàng xià liăng gè xué zóng suàn tōng chàng, 
(Jin Shan) up down two M body cavity on the whole ease up,

(e) (shí wù pái xiè wù) jìn chū wú ài .......

(food and excreta) enter out no obstacle

[Translation] They dosed him with herbs. But as expected, it did not help. And so they ended up by feeding him rice and water. Fortunately, two cavities in Jin Shan's body are eased up, so food and excreta come in and out smoothly. (Liu Heng, Fuxi Fuxi)

The fifth ZA in clause (e) can be identified with the referent "food and excreta" which has never been mentioned in the text, not even in the excerpted fiction. However, this referent "food and excreta" can be inferred from the context. In this passage, referents of other ZAs have been explicitly mentioned in the larger text, but are invisible here. Therefore, the relationship between $\mathrm{ZA}$ and its referent in this case is quite different from the cases mentioned above, and the referent of $\mathrm{ZA}$ in this case is implicit in comparison with others.

\subsection{Ambiguous Referent}

It is not surprising that many zero anaphors can be recovered from several referents. However, in some situations, it is almost impossible to trace the referent for a ZA in Chinese discourse. For example,

[8](a) jīn zi xiān 1 xīn xiăng, zì jǐ zhēn shì pèng shàng dà hăo rén。 Jin Zi xian think, himself really meet up very kind person

(b) Ø $\varnothing_{1}$ qiān ēn wàn xiè zhī hòu, $\varnothing_{1}$ biàn chuāi qũ fāng zǐ kuài kuài huó huó qù zhuā yào 。

(jīn zixiān) many thanks after, (jīn zixiān)at once carry-up prescription happily go buy medicine

(c) $\varnothing$ (?) huí qù àn fâng yī yòng,

( jīn zi xiān ? shă èr ? they?) back try remedy, 。

(d) ø (? ) guǒ jiàn chéng xiào

(hair? remedy? prescription?) expectedly effective.

(e)bù duō tiān, shă èr de tóu fà jiàn jiàn biàn hēi biàn liàng,

Not many days, Shaer DE hair gradually become black become shiny,

(f)ø fãng fú yòng yóu yān mò yí biàn biàn răn shàng de 。

as if use black oil ink repeatedly dye up DE.

(g)ø suí hòu jiù yăn kàn zhù cū qǐ lái, (hair) then MA eye see PTCP thicken up,

(h)ø yǒu rú chūn tiān de căo zhī。 bàn yuè hòu, (hair) like spring DE grass tree branch. Half month later,

(i)( tā men ) hū jiàn měi gēn tóu fà dōu gǒng chū wū hēi zhăn liàng de jiān zi lái, $\cdots$ (they ?) suddenly see each $M$ hair all sprout forth black glistening DE point come,

(j) Ø hăo xiàng cuàn yá bá jié,

(-) as if new bud growing shoot,

[Translation] Jin Zixian thought that this time he had really met a good person. After many and profuse thanks, he tucked away the prescriptions and rushed off to get the medicines. When he got home and they tried the remedies accordingly, they found that they really were effective. Within a few days, Second Simpleton' s hair began to turn black and shiny as if it had been dyed repeatedly with black oil ink, and then they could see it growing thicker like grass in spring. Half a month later, they suddenly saw that each strand of hair had sprouted 
forth a black and glistening point*..(féng jì cái shén biān )

The form of single line clearly shows the elliptic content for each ZA which is made prominent through dotted line frames.

bù duō tiān, shă èr de tóu fà jiàn jiàn biàn hēi biàn liàng,

hă èr de tóu fà făng fú yòng yóu yān mò yí biàn biàn răn shàng de 。

hă èr de tóu fà ssuí hòu jiù yăn kàn zhù cū qĩ lái,

hă èr de tóu fà jyǒu rú chūn tiān de căo zhī。

bàn yuè hòu, hū jiàn měi gēn tóu fà dōu gǒng chū wū hēi zhăn liàng de jiān zi lái,

měi gên tóu fầ dōu gǒng chū wū hêi zhăn liàng de jiān zi láí, hăo xiàng cuàn yá bá jié, (j)

The elliptic content shows that the ZA in clause $(j)$ is identified with the object clause in the prior sentence, but the ZA in $(\mathrm{k})$ has a collective antecedent which includes the antecedent of ZA in (j) and the clause (j) itself. We must return to the beginning for several ZAs. The ZA in clause (c) can be recovered from several referents: they, Sha'er(Jin's daughter-in-law) or Jin Zixian. For native speakers, one of the three referents is acceptable and comprehensible in discourse. The ZA in (d) also has several options to be identified: hair, medicine, prescription. In clause (i), the agent is absent, but the agent will be optionally "they, you or we", and this kind of sentence construction is prevalent in Chinese, such as "dan jian (just see)" etc. It is unusual in that the doer of the action or the agent is often not mentioned in a clause, and it is also difficult to recover the agent, hence there is a traditional tendency to omit the agent in Chinese.

\subsection{The Previous Approaches}

These examples are neither special nor few; instead, they are prevalent in Chinese discourse. In the past, studies on Chinese ZA seldom mentioned such cases. We can at the least conclude that some zero anaphors are not necessarily accurately identified with antecedents which must be somewhere as a syntactic element and some ZAs have none of their antecedents in the text.

In previous studies, the term "complex anaphors" (Consten et al., 2007) has been used to indicate complicated decoding, distinct from direct nominal anaphors, but in fact the so-called complex anaphors are nominal expressions referring to propositionally structured referents while introducing them as unified entities into a text world model (Consten et al., 2007: 81). For example, Young drivers usually drive too fast. This event/ these events... "This event" or "these events" refers to the previous clause. In comparison with the cases above, these complex anaphors are not complex to the point of preventing understanding.

Some studies point out that an anaphor can refer to elements of the communicative situation 
(speakers, hearer etc.). For example, Rink \& Bower (1995) report how the accessibility of a referent for an anaphoric noun phrase decreases with the spatial distance of the referent within a situation model. These studies are significant to understand how the referents of anaphors change with the situation, particularly in conversation, but they are distinct from this study because what these referents can refer to in the real world is not our focus. Take the example mentioned above, Tom closed the door, ø went down the stairs. We only care about the ZA refers to 'Tom' in discourse, but what 'Tom' refers to (speaker or another person) is another problem in communication.

Cowles, Walenski and Kluender(2007) find that the information structure categories of topic and focus have the common effect of increasing the cognitive prominence of the referent of their linguistically prominent noun phrase. For pronouns with two possible antecedents, the cognitive prominence of an antecedent biases towards the more prominent antecedent. Their finding can explain why Chinese discourse prefers to use a co-referential topic as the referent of ZA; but it fails to explain the occurrence of a complex ZA mentioned in this study. Kehler \& Rohde (2013) take a Bayesian account of pronoun use: biases towards referents of pronouns are determined by combining the prior probability that a referent will get mentioned next and the likelihood that a pronoun will be used to mention that referent. Being consistent with Kehler \& Rohde (2013), the study of Zhang, Levy and Kehler (2016) shows that pronoun interpretation biases in Chinese reflect the joint influence of next-mention biases and production biases. Although a probability method provides a quite new perspective to understand anaphora, the anaphora in their studies is different from this study because a pronoun mentioned in these studies has one identified referent which occurs as a syntactic element in discourse.

Von Heusinger (2007) integrates 'activation', 'giveness hierarchy' (Gundel, Hedberg \& Zacharschi, 1993) and 'accessibility marking scale' (Ariel, 1990: 73) into a unified framework to explain the relation between anaphor and antecedent in discourse effectively (Figure 3). The framework is also helpful for explaining co-referential zero anaphors and their antecedents; however, it still cannot reveal how the complex referent of zero anaphors above operate.

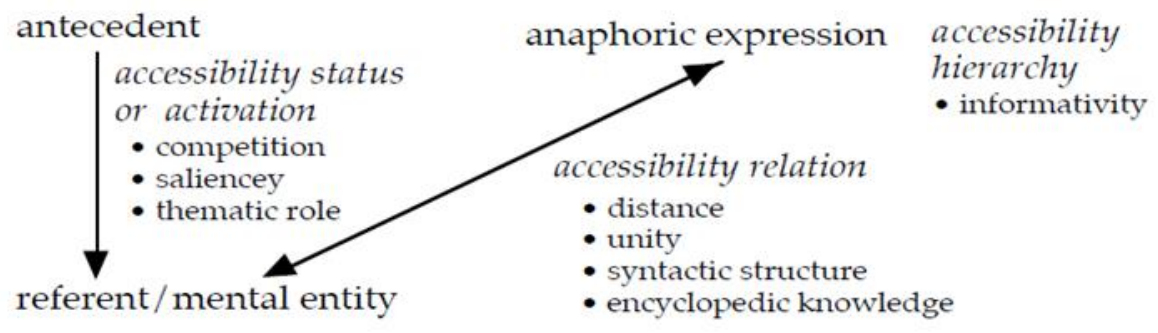


Figure 3: Heusinger's model for anaphora

These previous works are undertaken in order to explain why an antecedent located in a certain syntactic position can be co-referential with the anaphor, or interpret the complex anaphors. To clarify these complex zero anaphors in Chinese, some new approaches should be developed so as to interpret how they work and they should do so by taking account, to some extent, of Chinese characteristics.

\section{The Underlying Mechanism of Complex ZAs}

As discussed above, many theories have been used to explore the mechanism of ZAs in Chinese. The most famous ones are the topic chain, accessibility, pragmatic factors, discourse structure. As pointed out at the end of 1.3, these studies target those ZAs which are completely co-referential or quite different, and whose referents must occur at one certain syntactic position. The majority of previous studies follow these steps: identification of zero anaphors, and then location of antecedents, and further analysis of what factors have exerted their influence on zero anaphora. Therefore, these studies cannot clarify why these complex ZAs occur in Chinese discourse. We will tentatively explore some fundamental principles for explaining what causes the occurrences of these complex ZAs and propose one type of hypergraph to simulate cognitive process of dealing with these ZAs for Chinese speakers.

\subsection{Independent Phrases Working as Clauses}

Chinese has a tendency to make use of isolated phrases to work as clauses. This is quite different to English. In English, clauses can be roughly classified into two types: finite clauses and nonfinite clauses. According to the online Cambridge Dictionary, finite clauses must contain a verb which shows the tense. They can be main clauses or subordinate clauses. Non-finite clauses contain a verb which does not show the tense. Generally, non-finite verbs are used only in subordinate clauses. We usually understand the time referred to from the context of the main clause. A non-finite clause has a logical subject which is the same as the subject in the main clause. Put simply, finite clauses are required to be presented in the form of an $\mathrm{S}-\mathrm{V}$ structure. In contrast, subjects are invisible in non-finite clauses, and the subject in non-finite clauses which usually are subordinate is actually identified with the subject in the main clause. In comparison with English, Chinese tends to use some VPs independently in discourse. Moreover, some NPs can also be used 
independently. These VPs, in some cases, are not easily coupled with their subjects. Wang \& Li (2014) suggest that the fundamental discourse unit in Chinese discourse should be the phrase, a fact of grammar which also indicates that phrases can have the same function as clauses in Chinese. Consider some examples below.

[9] (a)xīn lái de kè rén zhōng, yŏu yī wèi jiào xú zhuàng tú de zhōng nián nán shì, newly-come DE guest in, there-be one M call Xu Zhuangtu DE middle-aged gentleman

(a) Ø shì shàng hăi jiāo tông dà xué de bì yè shēng ; (he ) is Shanghai Jiaotong University DE graduate;

(b) Ø shēng dé pǐn mào táng táng ,

(he) look handsome,

(c) gāo gāo de gè ér, tall DE height,

(d) jié shí de shēn tĩ , strong DE body,

(e) $\varnothing$ chuān zhe jiăn cái hé dù de xī zhuāng ,

(he) wear PFV M suitable DE suit

(f) $\varnothing$ xiăn dé fèn wài yīng tǐng 。

(he) look especially handsome and straightly.

It's noted that in (d) and (e), two NPs are not integrated into other clauses as syntactic elements, hence they are independent. Actually, the function of those two NPs is equal to two clauses. Native speakers of Chinese understand them as "(Xu Zhuangtu has) a tall and strong body", or "(Xu grows with) a tall and strong body". Sequence (c), for example, looks like an independent VP, but it is easy to confirm that its complete form is an S-V structure: "(Xu) looks handsome". By contrast, (d) can be recovered in two S-V forms: "(Xu has) a tall and strong body", or "(Xu grows with) a tall and strong body". Its elliptic content is an S-V structure, hence the situation is quite different from (c).

Phrases can function directly as a finite clause in Chinese discourse, and these phrases work independently; they are not syntactically integrated into other clauses. When a phrase playing a clausal role is expressed as a VP, it is not easy to find the subject of the VP or it has several possible subjects if the VP is required to recover S-V structure.

Zhu (1985) holds that any phrase plus intonation is likely to function as a sentence in Chinese. Chao (1969) believes that the sentence is a segment of utterance which is paused at both ends and which can occur as full sentence or minor sentence. A full sentence has both subject and predicate, while a minor sentence has either a subject or a predicate. A full sentence in Chinese, as made up of two minor sentences, is a normal and frequently used type of syntax in daily speech. A 
succession of two minor sentences does not necessarily make a full sentence (Shen 2012). Hence passages filled with these minor sentences are called "flowing sentences" that cannot be clarified by current grammatical theory.

If an independent phrase is a VP in discourse, the analyst is required to find its subject when the task of zero anaphora is fulfilled. We can find such examples among those in 2.3. and 2.4. The referent of one ZA for the VP is optional or it is sometimes quite difficult to identify. In some situations, the referent can be inferred from the context if the task of tracing is forcefully carried on, like clause (d) in [8]. What causes these phrases to work independently and makes those referents unidentified?

\subsection{Event Representation for Clause}

One series of studies (Speer et al., 2009) took a correlational approach, using narratives as test materials. Each story of the narratives was divided into clauses (defined as a verb plus its argument structure) and the participants read the text of one clause at a time. By presenting functional neuroimaging evidence, this study shows that readers understand a story by simulating the events in the story world and by updating their simulation, and then segment the activity in the stories. Therefore, the study conducted by Speer et al can prove that readers identify event boundaries in precisely those clauses, because one of the situation model dimensions (cause, character, goal, object, space and time) in each clause kept changing. Later, Kurby and Zacks (2012) used behavioral experiments to prove this finding. In a sense, one clause in an English narrative can be activated as an event.

"Single words, whether a verb denoting a common event or situation, or a noun denoting a typical participant, suffice to rapidly activate related event knowledge" (Hare et al., 2009). In previous studies on events, nouns and adjectives are treated as the manifestation of states or situations. Verbs are the expression of dynamism and nominals introduce the static perspective into discourse, according to traditional grammar.

As a matter of fact, nouns and adjectives in some languages, such as in Chinese discourse, can also express events. In English, one clause can be activated as an event in the neural system. One clause in English discourse has its counterpart — one independent phrase in Chinese discourse. Although there is no direct evidence in neural studies, it is reasonable to assume that Chinese readers are able to identify event boundaries in the guise of independent phrases or clauses in 
discourse.

What is an event? Generally speaking, an event can be roughly defined as a thing occurring at a certain location at a certain time, instead of actions. In a broad sense, the concept of "event" includes event, state and proposition; hence some studies use the term "eventuality" to refer to this broad concept of "event". The linguistic expression of each clause in Chinese discourse can be represented by events of knowledge.

Two clauses in English are combined through two different means: subordination and coordination. Sentences or clauses are coherently integrated through different cohesion devices, such as reference, ellipsis, lexical conjunction (Halliday \& Hasan, 1976). Later, more connective devices are identified by Quirk et al. (1985: 1437-1487), which are more elaborate than those given by Halliday and Hasan: pragmatic and semantic implications, intonation, punctuation, and information processing. That signifies that every clause will possibly be related to the adjoining clause in a subordinate or coordinate manner; otherwise the clause will be independent to exist as an $\mathrm{S}-\mathrm{V}$ form sentence.

In 3.1, it was mentioned that many independent phrases perform the role of clauses in Chinese discourse and these phrases do not involve syntactic processes in other clauses. If these phrases are to be coordinated with other clauses, they must be occurring as an $\mathrm{S}-\mathrm{V}$ form, but they are just phrases. Thus, when an attempt is made to use syntactic or semantic theory to explain how these independent phrases relate to other clauses, it is almost impossible to clarify these problems in a satisfactory way.

If a new perspective or a new pattern is created for reconstructing the clausal relationship, it will not change the nature of the relationship. However, it will bring forth the new approach to modes of thinking. It is difficult to perceive it in the old framework, but it can be clear, natural and simple in another framework.

When each clause is represented as an event, these independent phrases in Chinese discourse, VP, NP, AP or PP can be considered as independent events as well. Regardless of their grammatical functions (subordination, coordination, cohesive relation, etc.), the clausal relationship can be transformed into a relationship between events. The event relationship is possibly easier for gaining access to the nature of a clausal relationship. Another example is reproduced below:

[10](a) ø chì le jiăo , (Yingzi) barefoot, 
(a) Øài liáng jìn jìn huá huá liū de ní lǐ căi zhe ,
(Yingzi) in cool slippery DE mud in tramp PFV,

(c)-- āi , yí gè yìng gē da!

Ai! One $M$ hard knot!

(d) $\varnothing \quad$ shēn shǒu xià qu ,

(Yingzi) reach down into mud,

(e) yí gè hóng zǐ hóng zǐ de bí qí 。

One $M$ purplish-red DE water chestnut.

[Translation] Barefoot across the cold slippery mud, Yingzi suddenly felt a knot, reached down into the mud and caught a purplish-red water chestnut. (Wang Zengqi Shoujie)

Clauses (c) and (e) are manifested by NPs which are used independently, and do not integrate into the syntactic processes in other clauses. The current syntactic and semantic theories cannot clarify the syntactic and semantic functions of these independent NPs so well. The relationship between clauses with zero forms is implicit because no explicit connectives or other linking devices can be found among the five clauses. What makes the implicit relationship work out the tie with each clause so closely?

In Chinese, an event can be represented by a clause, but an event also can be manifested by an independent VP (or NP). Actually, the three clauses and two independent phrases can be considered as five related events. If $\mathrm{E}$ is used to symbolize an event, $\mathrm{E}_{(\mathrm{a})}, \mathrm{E}_{(\mathrm{b})}, \mathrm{E}_{(\mathrm{c})}, \mathrm{E}_{(\mathrm{d})}$ and $\mathrm{E}_{(\mathrm{e})}$ are separately taken to represent each event.

$\mathrm{E}_{(\mathrm{a})}$ - Yingzi took off shoes to be barefoot into mud;

$\mathrm{E}_{(\mathrm{b})}$ - Yingzi tramped in the cold mud;

$\mathrm{E}_{(\mathrm{c})}$-Yingzi felt a hard thing;

$E_{(d)}$-Yingzi reached down into the mud;

$\mathrm{E}_{(\mathrm{e})}$ - Yingzi dug out a red water chestnut.

Although $\mathrm{E}_{(\mathrm{c})}$ and $\mathrm{E}_{(\mathrm{e})}$ are signified by the form of NPs, they do not disturb the coherence of this passage. Chinese natives understand the macro-event to be composed of small events which are arrayed in accordance with their temporal succession. The relationship between successive events has been identified to be a progressive cause-effect link.

Ultimately, the five events make up an event chain which allows speakers/readers to narrate a sequence of small events by integrating them into a larger conceptual unit. For example, entering a restaurant, ordering and eating food can make up a complete event of eating in a restaurant. These small events will be organized according to some consequences. Temporal sequencing allows one to place such events along a timeline or time axis so that the listener/ reader comprehends that 
entering the restaurant occurred before ordering meals. Finally, causal connections help to characterize situations where one event makes another much more probable, for example, that lighting the fire caused the room to warm up.

Event, temporal and causal structures help organize experiences into more manageable units. The alliance of events can be viewed in two ways: as a sequence or as a hierarchy. When the events in discourse are organized as a sequence, the author of discourse indicates that these events will occur in a succession according to their chronological sequence or according to the spatial order of observing. When the events are arranged as a hierarchy, it means that they are often integrated into whole-part relations.

These five events are arrayed according to their chronological sequence and, in most cases, events are organized by their temporal succession in Chinese discourse. When an event advances forward chronologically, it does not necessarily require the use of grammatical devices, such as connectives, to indicate the explicit grammatical and logical relationships with its adjacent event.

If a ZA is required to trace its antecedent, two independent NPs (c) and (e) in [10] are still considered as having two ZAs prior to them. In (c), the complete form should be "(Yingzi used her feet to feel) a hard knot", such that the referent of this ZA is "Yingzi used her feet to feel". For (e), the referent of the ZA is "Yingzi dug out". Two referents share the same thing — "Yingzi", which occurs in context, whereas "used her feet to feel" and "dug out" do not occur.

Let us return to the example [9]. Seven clauses including two independent NPs can be looked upon as seven different events. The seven events are not arranged according to the temporal order; instead, they are threaded in accordance with hierarchy. Event (a), at the top of this hierarchy, controls other events at the bottom and the remaining events about Mr. Xu's educational background, appearance, height, body and clothing are used to portray $\mathrm{Xu}$. These events are optionally manifested by a complete clause, a VP or an NP. A Chinese speaker has a preference for using many VPs sharing the co-referential subject (topic); meanwhile, NPs are also allowed to occur independently in discourse. The following section will discuss what causes the occurrences of ZAs and independent phrases.

\subsection{Event Integration and Compression of Information}

Under the influence of economy of language and the integration of syntax and semantics, the clauses in Chinese discourse are often compacted through reducing some syntactic and semantic elements. So the subject (or the mixture of the subject and other elements) in a clause is often 
omitted in discourse. However, the aforementioned compactness should not be too extreme, for otherwise discourse will be shortened into a series of verb constructions.

In some cases English is likely to use several sentences and more linguistic codes to express the same information as compared to Chinese, which just employs several short clauses to form a short-length structure. After so many clauses are compressed into such a compact structure like a narrow passageway, the subject (the topic) in each clause will be omitted and sometimes the coreferential subject (topic) in the former/later clause will be invisible. Further, interestingly, connectives for these clauses do not necessarily occur. These omissions may be caused by a principle of economy in the Chinese language. However, the interpretation of economy principle is too rough.

Compression leads directly to the result that clauses are mostly arranged according to the natural and logical order. When readers/ hearers decode the passage where much information is assembled into this narrow passage, they must heavily rely on their logical arrangements in the physical world (such as Principle of Temporary Sequence, spatial order, cause-effect, etc.) and the co-referential topic to find implicit relationships, interpret logical connections and then understand the information in Chinese discourse. Sometimes the semantic relationships between clauses are left implicit, such that interpretation may sometimes require considerable creativity on Chinese speakers/ readers.

In 3.2, it was mentioned that, according to some research findings, one clause in discourse can be represented as an event in human neural system and several events are arrayed by obeying a certain ordering to constitute an event chain or a macro-event. For a macro-event, it can be considered as a combination of several events. The following figure shows their relationship.

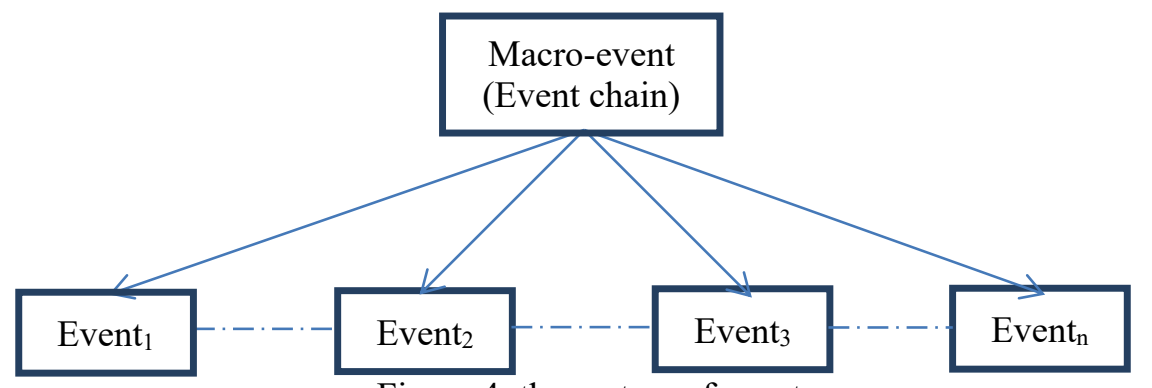

Figure 4: the system of events

When one clause occurs independently, its components will be quite different from the situation when the clause is used in discourse. When the clause occurs in discourse, its structure can be compressed to some degree. Compression means that some components in a complete clause will 
be omitted when it occurs in discourse. The frequently omitted components are co-referential subjects, connectives, some tense/aspect markers, modality, etc.

We know that verbs are easier to be associated with events though nouns or adjectives can be represented as events. After some syntactic and semantic categories in originally complete clauses are deleted, the remaining core verbs in each clause are much more likely to be represented as an event so that quickening the process of event integration is enabled.

The integration of events is a very effective strategy for Chinese natives to process and comprehend the main information in the discourse. The co-referential ZAs and the remaining verbs through deletion make the event integration become easier and quicker.

Event integration cross clauses has been observed in other studies, for example, "The more two events share their referents, the more likely they are to be construed as a single event" (Givon 2001:50). Event integration is also likely to occur within a clause. Talmy(2000:214-221) explores how to deal with event integration in a complex sentences.

In 2.1, the nominal referents of some zeros are derived from the previous clauses through gradual accumulation, but sometimes their antecedents are not always nominal. The gradual omission is considered as the result of the compactness that is required by Chinese linguistic economy. Clauses (e), (f) and (g) in [4] symbolize three related events, shown as follows:

$\mathrm{E}$ (e) (wheat fruit fineleaf) pound press juice,

$E_{(f)}$ (wheat fruit fineleaf pound press juice) knead into dough make into cake,

$\mathrm{E}_{(\mathrm{g})}$ (wheat fruit fineleaf made into eake) call yellow flower wheat fruit cake.

When the three clauses are arrayed according to the temporal sequence, they have been compressed just to highlight their core event characteristics through the prominent verbs which can be under the spotlight through the deletion of subjects or subject with other elements which have occurred previously. Prominent verbs in each clause are new information which never occurs before, and these prominent verbs are highlighted through the deletion of those subjects and other elements which are old information, such that these verbs are quite easier to be processed into an event by Chinese natives, and these events represented by prominent verbs in each clause are prone to foster event integration. The three events captured through prominent verbs, 'press juice', 'make into cake' and 'call some cake' are fairly convenient to be integrated to produce the global meaning '(fineleaf) press juice to make into cake called some'. Hence, Chinese natives have a quickening process of the main information in discourse. 
We have discussed what kind of syntactic elements are easier to be deleted. Now we should examine what the referent of ZA includes, which is from another perspective. The referents of some ZAs can be obtained from different syntactic elements, even from different clauses. These elements omitted are old information which maybe occurs at different locations. As mentioned previously, each clause can be considered as a related event, and these events are generally arrayed according to some cognitive orders. The deletion of the old information helps these related events to be integrated together in order to make the main information easier to be captured, such that Chinese natives can process the discourse and capture the information as quickly as possible. Consider the three clauses in [6].

$E_{\text {(c) }}$ (Anhui Province water-logging disaster in Huai River area) mainly appear between July and August,

E (d) (Anhui Province water-logging disaster ) secondly the Yang-tze River area, E (e) (Anhui Province water-logging disaster in Yang tze area) mostly appears....

As analyzed in 2.2, the three clauses in [6] show that the omitted part (the referent of ZA) in each clause is obtained by extracting several syntactic elements. Although these referents are different, they have a shared component "Anhui Province water-logging disaster" in [6], and "wheat fruit fine leaf" in [4]. The shared component is the topic (not only the propositional topic but partially co-referential anaphor in each clause) which controls each clause through its coreferential mechanism. When each referent of zero anaphor contains the co-referential topic, the referent of ZA can absorb other components, like [4] and [6]. The following graph is provided to represent the referents of zero anaphors.

\section{$\emptyset_{1}\left(=T+\operatorname{Var}_{1}\right) \ldots \ldots \varnothing_{2}\left(=T+\operatorname{Var}_{2}\right) \ldots \ldots . \varnothing_{3}(=T+\operatorname{Var} 3) \ldots \ldots \varnothing_{n}\left(=T+\operatorname{Var}_{n}\right)$}

$\mathrm{T}=$ topic (co-referential)

Var = other components derived from context. Var can be empty, and in most cases it can contain three elements, so the referent of a zero anaphor has four elements at the most.

The referent of the following ZA is likely to be obtained through selecting some components of the preceding clause. The referent of ZA in clause (e) in [6] has been formed by deriving some components "in the Yang-tze River" in clause (d) and storing the co-referential topic. The same procedure occurs in the referent of ZA for clause (c). The referent of one ZA can be something which is a combination of different elements through the reorganization of some of the elements of preceding clauses. Consider the following example 
[11] (a) tā men jīng cháng dă pái 。

They(monks) often gambling.

(b) zhè shì gè dă pái de hăo dì fāng 。

This is $M$ gambling $D E$ good place.

(c) ø, bă dà diàn shàng chī fàn de fāng zhuō wăng mén kǒu yī dā, (they) BA main hall for meal DE square table to entrance take

(d) $\varnothing_{2} \quad$ xié fàng zhe , (they BA the square table) slant PFV,

(e) $\varnothing_{3}$ jiù shì pái zhuō 。

(the table they slanted) right is gambling table.

[Translation] The monks loved gambling. The square table in the main hall, which was used for meals, was just right for this, and would be moved to the entrance of the hall.

In [11], the second ZA in clause (d) has its referent "they + BA(把) + the square table" which is consisted of the co-referential topic "they (monks)" and some components selectively derived from clause (c). The components "BA" and "the square table" are scattered over the clause (c). The third zero anaphor can be recovered as "the table they slanted" which still contains the coreferential topic "they" and other components "the table" and "slanted" derived from the preceding clause (d). All referents of ZAs have occurred in discourse, and are therefore deleted as old information in order to highlight new information (prominent verbs). The referent is not the result of direct derivation, but rather a matter of re-organization and the process is shown as the following figure.

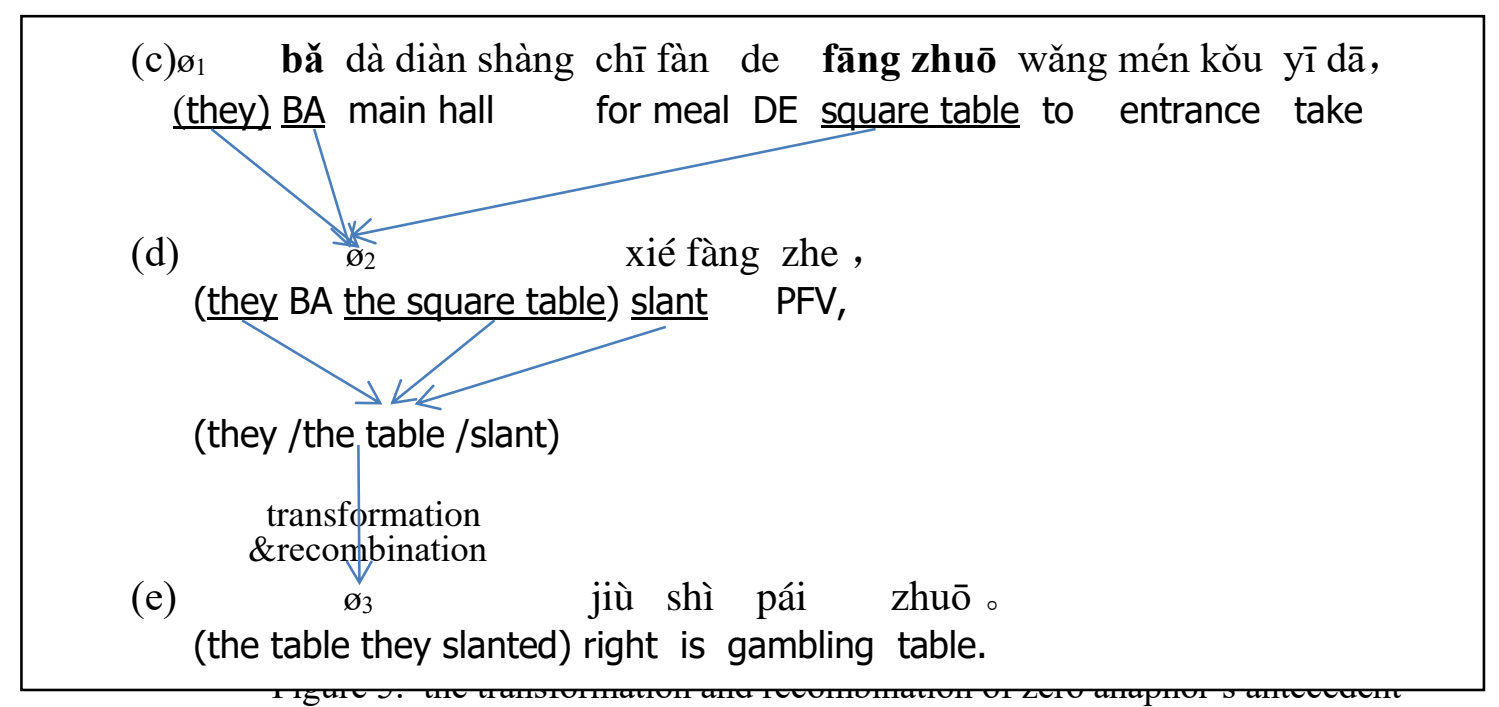

According to Cown (2001), the working memory store is limited to 3 up to 5 (4 \pm 1 ) meaningful items in young adults. The referent of zero anaphor in one clause can be derived from the preceding clause, which can be considered as one iteration. However, the number of iterations 
cannot extend beyond five, for otherwise its load far exceeds the human working memory capacity.

After clauses have been compressed, Chinese can make use of co-referential topics, cognitive ordering (such as temporal sequence, spatial order, cause-effect links, etc.) and the quick integration of events through contiguous independent VPs, so as to enhance discourse coherence. All these help readers/hearers grasp the meaning of discourse effectively.

In a few cases, the prominent verbs in a complete clause are deleted after compression, like clauses (c) and (e) in [10]. Independent NPs (or PPs) without verbs still express an event concept, but their function, different from independent VPs, is to highlight the result of this event which can be activated by its relevant noun or adjective, according to Hare et al. (2009). For example, in [10], (c) and (e) stress on the discovering of Yingzi's actions, "(felt) a knot" and "(caught) a chestnut".

Also there are two independent NPs in [9]. Clause c can be recovered into "(Xu has / grows with) tall height," and (d) can be recovered in "(Xu has / grows with) a tall and strong body". The two independent NPs can be treated as the result of deleting subject and predicate verb. Here two NPs are more effective to give prominence of Xu's appearance than VPs or SV structures, particularly in expressing static features.

It is noted that the compacted information in Chinese discourse generates many special linguistic phenomena in syntax and semantics, therefore many linguists working on Chinese claim that Chinese is a language that heavily relies on textual analysis and pragmatics.

Despite of the fact that co-referential topics, cognitive ordering and the quick integration of events through deletion old information are quick and convenient to help readers/ hearers process discourse effectively, the convenient strategy has negative effect on ZAs which become quite complex and tricky. For example, as analyzed in this study, some ZAs are derived through the combination of different element and reorganization, and some ZAs have several optional referents. These ZAs are obviously more complex than co-referential ZA.

In summary, by making use of zero anaphors, co-referential topic and cognitive order, Chinese discourse becomes compact and concise as regards the economic considerations, allowing speakers processing it quickly through event integration, but pays the cost of the complexity of zero anaphors.

\subsection{Hypergraph for Complex ZAs}

The section will discuss how possible is it that Chinese natives deal with these complex ZAs 
in theory by the use of special algorithm to simulate.

The use of the semantic map has become popular and effective in cross-linguistic studies and cognitive studies (Haspelmath 2003, Sonia 2007). Huth et al.(2016) have mapped the brain areas that respond to words according to the semantics of each word (a detailed semantic atlas). These semantic maps are extremely similar in different individuals. In spite of the various ways that are used to create semantic maps, semantic maps are essentially hypergraphs.

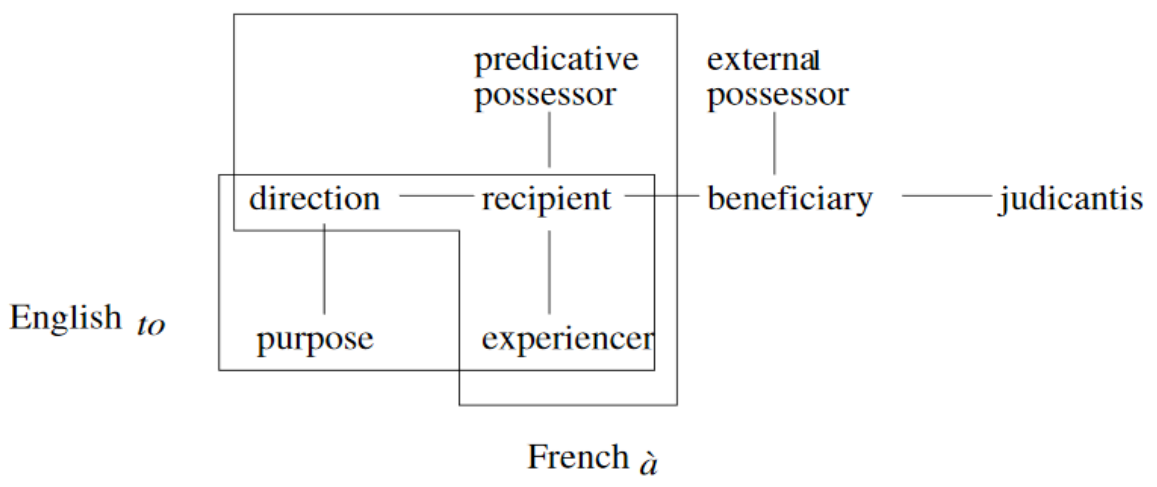

Figure 6: Semantic maps of typical dative functions (Haspelmath 2003: 213-5)

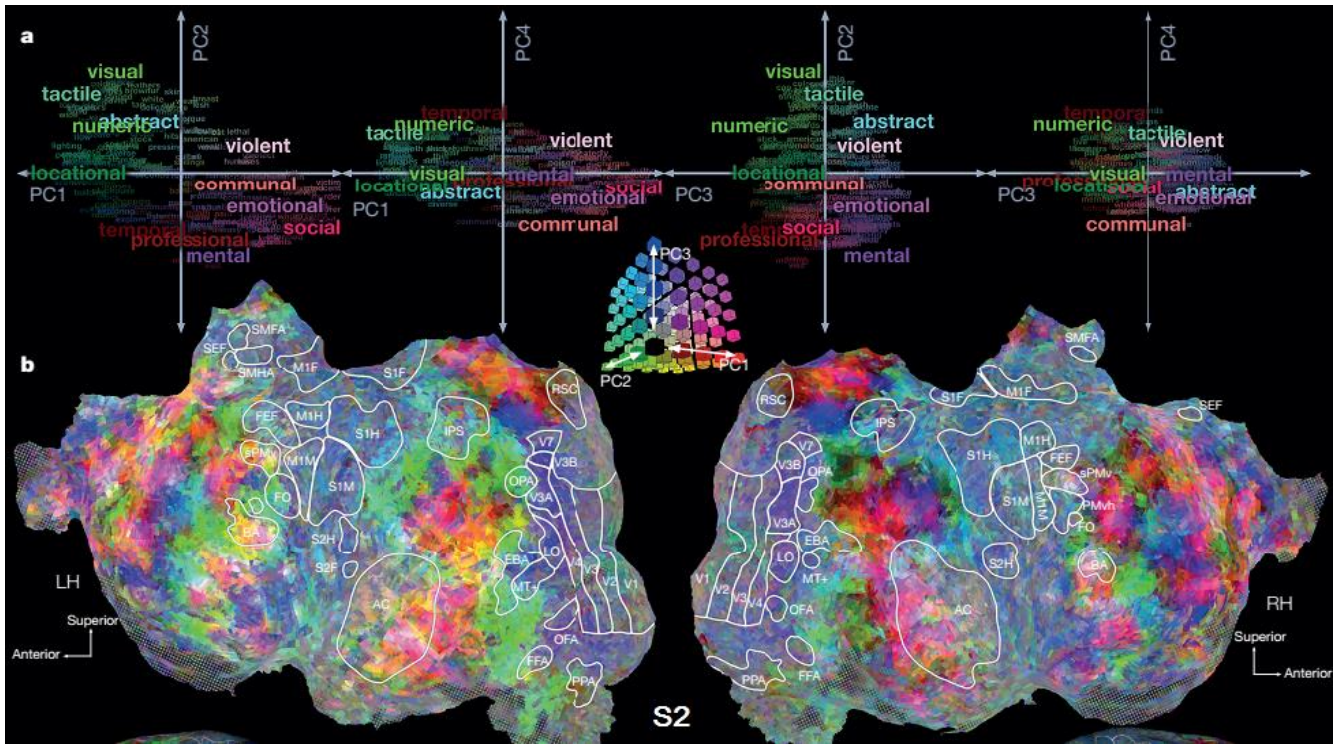

Figure 7: word semantic maps in brain(Huth et al 2016)

A hypergraph can be used to represent the complex relationships among entities in a Chinese zero anaphor mentioned above. What is a hypergraph? "The basic idea of the hypergraph concept is to consider such a generalization of a graph in which any subset of a given set may be an edge rather than two-element subsets."(Voloshin 2009:135). The following figure is a hypergraph. 


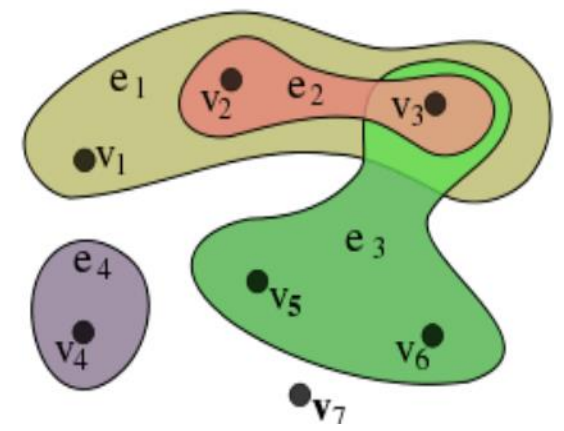

Figure 8: a hypergraph example (from https://en.wikipedia.org/wiki/Hypergraph)

Here, $v$ means vertex, and $e$ means edge, Formally, a hypergraph $\mathrm{H}$ is a pair $\mathrm{H}=(\mathrm{X}, \mathrm{E})$ where $\mathrm{X}$ is a set of elements called nodes or vertices, and $\mathrm{E}$ is a set of non-empty subsets of $\mathrm{X}$ called hyperedges or edges. In the example above, $X=\{v 1, v 2, v 3, v 4, v 5, v 6, v 7\}$ and $E=\{e 1, e 2$, $\mathrm{e} 3, \mathrm{e} 4\}=\{\{\mathrm{v} 1, \mathrm{v} 2, \mathrm{v} 3\},\{\mathrm{v} 3, \mathrm{v} 5, \mathrm{v} 6\},\{\mathrm{v} 4\}\}$.

Therefore a hypergraph $\mathrm{H}$ denoted by $\mathrm{H}=\left(\mathrm{V} ; \mathrm{E}=\left(e_{i}\right)_{i \in I}\right)$ on a finite set $\mathrm{V}$ is a family $\left(e_{i}\right)_{i \in}$ ${ }_{I},(I$ is a finite set of indexes) of subsets of V called hyperedges. Sometimes V is denoted by $\mathrm{V}(\mathrm{H})$ and $\mathrm{E}$ by $\mathrm{E}(\mathrm{H})$. Example 6 is taken to show how a complex ZA is represented as a hypergraph.

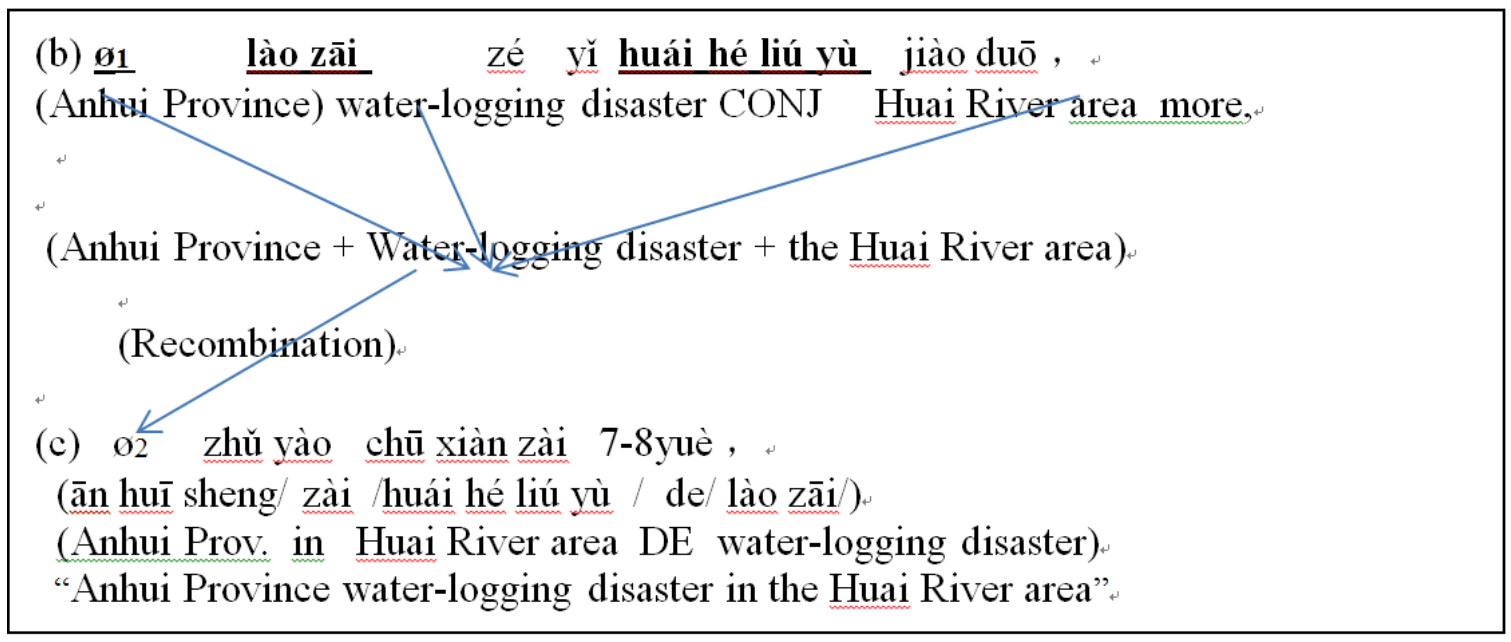

This ZA in (c) of Example 6 can be recovered as an entity consisting of four elements: Anhui Province / water-logging disaster/ zài(in) / the Huai River area. The other zero anaphor in this example has a complex referent, also consisting of four elements, Anhui Province / water-logging / zài (in) / Yang-tze River area. However, the two zero anaphors contain the same element "Anhui Province" which is co-referential topic in this passage. As discussed in 3.3, one element in the antecedent is considered as one iteration, but the number of iterations cannot extend beyond five. Suppose we have three such zero anaphors, each antecedent with four elements contains a coreferential topic, such that three zero anaphors can be represented by a hypergraph. 
In this hypergraph, e1, e 2 and e 3 denote three zero anaphors, and $\mathrm{x} 1$ (x here means vertex) signifies the co-referential topic "Anhui Province" with other $\mathrm{x}(\mathrm{s})$ expressing other elements in a zero anaphor, and x5 for "water-logging" shared by two zero anaphors. In Chinese discourse, nouns (or NPs) in a clause are easier to be extracted into the elements of the antecedent of a complex zero anaphor, so nouns (NPs) can quite possibly become vertexes in a hypergraph of this complex zero anaphor. Finally, the relationship of zero anaphors is represented in the following hypergraph (Figure 8).
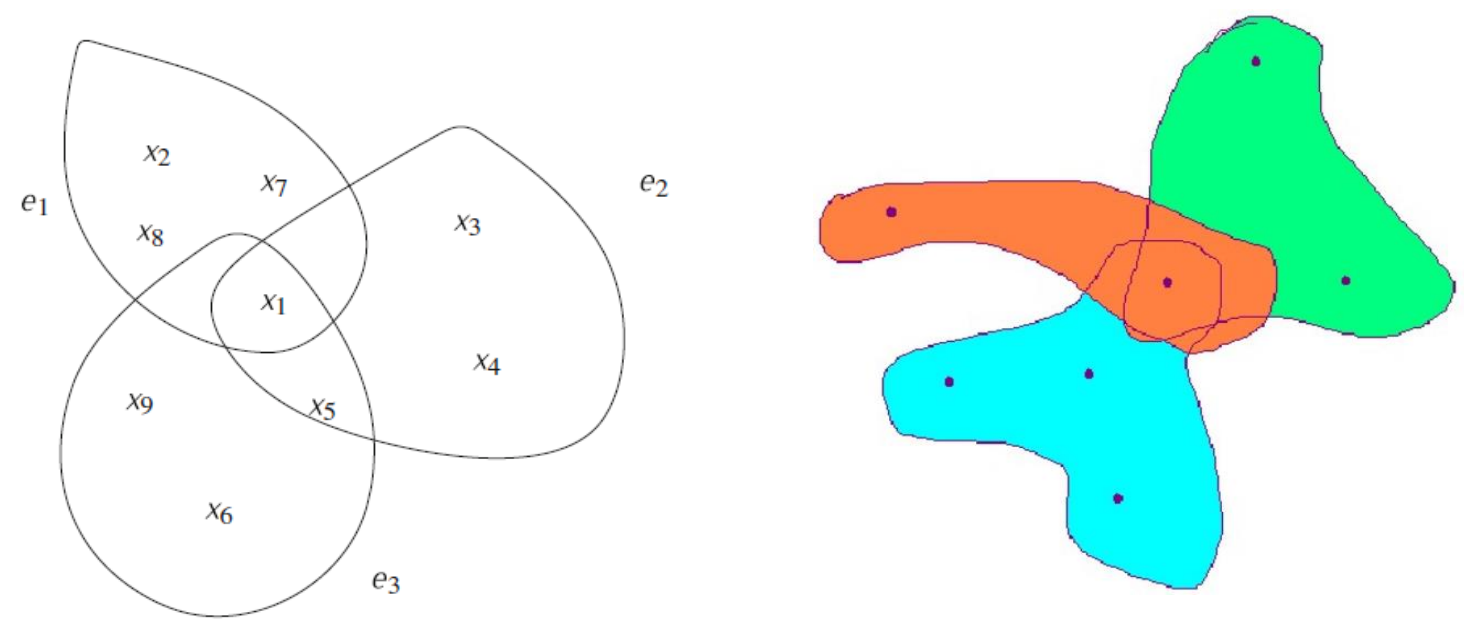

Figure 9: a hypergraph example of a complex zero anaphor Figure 9: a possible hypergraph for a In the above graph:

Chinese complex zero anaphor

- Let $\mathrm{V}=\{\mathrm{x} 1 ; \mathrm{x} 2 ; \mathrm{x} 3 ; \mathrm{x} 4 ; \mathrm{x} 5 ; \mathrm{x} 6 ; \mathrm{x} 7 ; \mathrm{x} 8\}$

- $E=\{e 1=\{x 1 ; x 2 ; x 7 ; x 8\} ; e 2=\{x 1 ; x 3 ; x 4 ; x 5\} ; e 3=\{x 1 ; x 5 ; x 6 ; x 9\}\}$

The concept of hypergraph can be generalized by allowing hyperedges to become vertices. Consequently, a hyperedge $e$ may not only contain vertices, but may also contain hyperedges, which are supposed different from $e$. The incidence matrix of this type of hypergraph is a matrix, which size is the cardinality of $\mathrm{E}$ and the cardinality of $\mathrm{V}$ plus the cardinality of $\mathrm{E}$.

$\mathrm{G}=(\mathrm{V}, \mathrm{E}, \mathrm{w})$

Degree of vertex, d (v) $=\sum_{\{\mathrm{e} \in \mathrm{E} \mid \mathrm{ve}\}} \mathrm{w}(\mathrm{e})$

Degree of hyperedge, $\sigma(e)=|e|$

The matrices of the hypergraph can be expressed as follows: 


$$
\mathrm{H}(\mathrm{v}, \mathrm{e})\left\{\begin{array}{c}
1 ; \mathrm{x} \in \mathrm{e} \\
0 ; \text { otherwise }
\end{array}\right.
$$

So we can get the matrix of the above hypergraph. Hassan et al. (2014) designed a random walk-based model to identify semantic polarity words. We adopt some algorithms to compare how much time will be cost in a hypergraph and a tree. Imagine a random surfer walking along the word relatedness graph G. Starting from a word entity $i$, it moves to a node $j$ with probability $P_{i j}$ after the first step. The walk continues until the surfer hits a node with a zero form. Zero forms act as an absorbing boundary for the random walk. If we repeat the number of random walks $N$ times, the percentage of times in which the walk ends at a zero form could be used as an indicator. The average time a random walk starting at $w$ takes to hit the set of nodes is also an indicator of zero forms. Let $W$ be the set of words in discourse (considering the fact that nouns, $20 \%$ words in Chinese being nouns, are mostly extracted as nodes). Consider nodes $V$ are all words in $W$. Edges $E$ correspond to the relatedness between words. Define the transition probability $\mathrm{P}_{\mathrm{t}+1 \mid t}(j \mid i)$ from $i$ to $j$ by normalizing the weights of the edges out of node $i$, so:

$$
\mathrm{P}_{\mathrm{t}+1 \mid \mathrm{t}}(j \mid i)=\mathrm{W}_{\mathrm{ij}} / \sum_{\mathrm{k}} \mathrm{W}_{\mathrm{ij}}
$$

The average length of Chinese clause contains seven words; therefore a hypergraph for the most complex ZA has 1/210 transition probability.

In most cases, ZAs and their antecedents will form a simple graph. However, the switchreference pattern of ZA (Example 3) is more complex than common co-referential ZAs. In Figure 9, R means referent, and a single ZA has 1/2 transition probability, but in the ZA chain, each ZA will have at least 1/12 transition probability when there are six ZAs (but in fact the number of ZAs might be more than six), such that the time cost in hypergraph is much more than that in coreferential ZA.

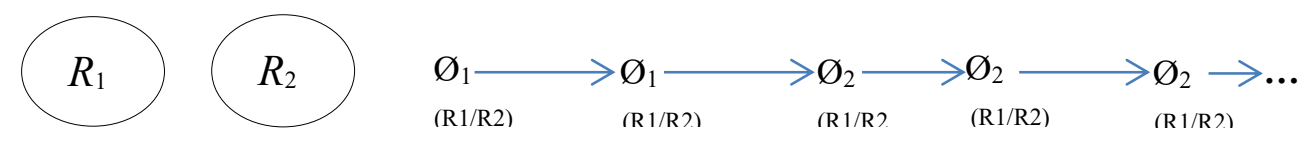

Figure 10: a transition probability of zero co-reference in Chinese discourse

However, if the strategy of hypergraph is replaced by a co-referential ZA, the remaining six referent candidates (each clause with ZA has an object which is likely to become a referent 
candidate) must occur in each clause, leading to the overload of redundant information. The efficiency of hypergraph and simple graph by the use of random work method can be compared. Therefore, a simple graph will have 1/72 transition probability if a speaker has to process extra eight syntactic elements. In such a sense, the time cost in hypergraph (the most complex ZA) is just almost threefold than the time cost by a simple graph. However, when the number of ZAs in such switch reference pattern reaches 10 , the value of its transition probability will become 1/200. At this moment, its transition probability is almost equal to the most complex ZA. If the number of ZAs in such switch reference pattern is beyond 10, its transition probability will be lower than the most complex ZA. So it is hard to say which one has higher transition probability because it depends on how many ZAs a switch reference pattern contains.

Roughly speaking, when Chinese speakers process them, the efficiency of a complex ZA is not necessarily lower than the one common ZA. Even we can assume that Chinese speakers are able to deal with the combination of several elements for a complex ZA as quickly as a common ZA. More cognitive experiments are needed to verify this estimate, in spite of the fact that quite few cognitive studies about Chinese zero anaphora have been done.

\section{Conclusion}

Chinese zero anaphora in discourse have been mainly explored by three approaches. These studies agree, for the most part, that every zero anaphor has its identified antecedent and they purport to explain what factors influence the occurrence of ZA. In opposition to previous studies, this paper finds that not every zero anaphor has its identified antecedent in discourse through illustrations of some typical examples. In other words, a zero anaphor in Chinese discourse has its referent, but not necessarily its antecedent. We find the antecedents of some ZAs can be identified through accumulation or reorganization, by means of absorbing constituents from clauses. However, sometimes antecedents never occur in discourse. Most theories on anaphora cannot sufficiently explain these cases. Therefore, attempts have been made to interpret what happens to these developments. The resulting explanations can provide useful guidelines, but are still relatively rough, such that they are imprecise as regards the detailed explanation of the complexity of antecedents. This will be a task for further research work. 


\section{References:}

Ariel, Mira. 1990. Accessing Noun-Phrase Antecedents. London/New York: Routledge.

Brown, Gillian. \& Yule, George.1983. Discourse Analysis. Cambridge: Cambridge University Press.

Chafe, Wallace. 1994. Discourse, Consciousness, and Time: The Flow and Displacement of Conscious Experience in Speaking and Writing. Chicago: The University of Chicago Press.

Chao, Yuanren. 1968. A Grammar of Spoken Chinese. Berkeley: California University Press.

Chen, Ping. 1986. Reference Introducing and Tracking in Chinese Narrative. $\mathrm{PhD}$ dissertation of University of California Los Angles.

Cheng, Chin-Chuan. 1988. Tongxin benwei hanyu pianzhang yufa [Communication-based Chinese discourse grammar]. Shijie Hanyu Jiaoxue[Chinese Teaching in the World](1):6-13.

Consten, M., Knees, M. and Schwarz-Friesel, M. 2007. The function of complex anaphors in texts: evidence from corpus studies and ontological considerations. Anaphors in Text, ed. by M. Schwarz-Friesl et al, 103-122. Amsterdam: John Benjamins.

Cowan, Nelson. 2001. The magical number 4 in short-term memory: A reconsideration of mental storage capacity. Behavioral and Brain Sciences 24 (1): 87-114.

Cowles, Wind. H., Walenski, Matthew. and Kluender, Robert. 2007. Linguistic and cognitive prominence in anaphor resolution: topic, constrative focus and pronouns. Topoi-an International Review of Philosophy, 26(1)3-18.

Devlin, Keith. 2000. The Language of Mathematics: Making the Invisible Visible .New York: W. H. Freeman and Company.

Dipper, Stefanie. et al. 2011. Abstract anaphors in German and English. in Iris, Hendrickx. et al(eds.) Anaphora Processing and Applications. Berlin: Springer.

Du Bois, John W. 1980. Beyond Definiteness: The Trace of Identity in Discourse.The Pear Stories: Cognitive, Cultural, and Linguistic Aspects of Narrative Production, ed. by Wallace L. Chafe, 203-74. Norwood, NJ: Ablex.

van Dijk, Teun. A., \& Kintsch, Walter. 1983. Strategies of Discourse Comprehension. New York: Academic Press.

Fox, Barbara. 1987. Discourse Structure and Anaphora: written and conversational English. Cambridge: Cambridge University Press.

Hare, Mary. et al. 2009. Activating event knowledge. Cognition (111):151-167.

Gordon, Peter. C., \& Chan, D. 1995. Pronouns, passives and discourse coherence. Journal of Memory and Language, 34:216-23 1.

Givón, Talmy. Topic Continuity in Discourse: An Introduction. Topic Continuity in Discourse: A Quantitative Cross-Linguistic Study, ed. by Talmy, Givon. msterdam: John Benjamins, 1983.

Givon, Talmy. 2001. Sytanx: An Introduction (II). Amsterdam: John Benjamins. 
Gundel, J. N, Hedberg \& R. Zacharski. Cognitive Status and the Form of Referring Expressions in Discourse. Language, 1993 (69):274-307

Halliday, Miacheal.A.K \& Ruqaiya. Hasan. Cohesion in English. London: Longman, 1976.

Hassan, A. et al. 2014. A random walk-based model for identifying semantic orientation. Computational Linguistics, 40(3): 539-562.

Haspelmath, Martin. 2003. The geometry of grammatical meaning: semantic maps and crosslinguistic comparison. In M. Tomasello (ed.), The New Psychology of Language, vol. 2, New York: Erlbaum, 211-243.

Huth, A. G. et al. 2016. Natural speech reveals the semantic maps that tile human cerebral cortex. Nature, 532, 453-458

Huang, James.C.T. 1982. Logical Relations in Chinese and the Theory of Grammar. CA Massachusetts: MIT dissertation..

Huang, Yan. 2000. Anaphora: A Cross-linguistics Approach. Oxford: Oxford University Press.

Huang, Yan. 2007. The Syntax and Pragmatics of Anaphora: A Study with Special Reference to Chinese. Cambridge: Cambridge University Press.

Jurafsky, Daneil. \& James, H. Martin. 2009. Speech and Language Processing. New Jersey: Pearson.

Kehler, Andrew. \& Rohde,Hannah. 2013. A probabilistic reconciliation of coherence-driven and centering-driven theories of pronoun interpretation, Theoretical Linguistics, 39(1-2) :1-37.

Kintsch, Walter. \& Van Dijk, Teun.A. 1978. Toward a model of text comprehension and production. Psychological Review, 85 (5), 363-394.

Kurby, Christopher.A. \& Zacks, Jeffrey.M. 2012. Age differences in the perception of hierarchical structure in events. Memory \& Cognition, 39, 75-91.

Lee, Cher-Leng. 2003. Zero Anaphora in Chinese. Taipei: Crane Publisher.

Li, Charles.N. \& S.A. Thompson. 1979. Subject and Topic: A New Typology of Language. Subject and Topic, ed. by Li, C. N., 457-61. New York: Academic Press.

Liu, Wenxia.2009.Hanyu lingxingshi huizhi yanjiu zongshu [A review of Chinese zero anaphors]. Qinghai Shifan Daxue Xuebao [The Journal of Qinghai Normal University]2009(6):100-105.

Pustejovsky, James.1991. The syntax of event structure. Cognition, 41:47-81.

Quirk, Randolph, et al. 1985. A Comprehensive Grammar of the English Language. London: Longman.

Rinck. Mike. \& Bower, Gordon, H. 1995. Anaphora resolution and the focus of attention in situation models. Journal of Memory and Language, 34(1):110-131.

Shen. Jiaxuan. 2012. "Lingju" he "Liushuiju"-wei Chao Yuanren xiansheng dancheng 120zhounian erzuo ["minor clauses" and "flowing sentence"-in memorial of 120 birthday of Mr. Chao Yuanren]. Zhongguo Yuwen [Studies of the Chinese Language ](5):403-415.

Sonia, Cristofaro. 2007. Semantic Maps and Mental Representation. http://www.eva.mpg.de/lingua/conference/07-SemanticMaps/files/manuscripts.html

Speer, Nicole. K. et al. 2009. Reading Stories Activates Neural Representations of Visual and Motor Experiences . Psychological Science. 20(8): 989-999.

Strazny, Philipp(ed.). 2005. Encyclopedia of Linguistics. New York: Fitzroy Dearborn.

Sun, Kun. 2015. Hanyu huatilian fanchou, jiegou yu gongneng [The category, structure and 
function of the topic chain in Chinese]. Yuyan Jiaoxue yu Yanjiu [Language Teaching and Research] 2015(5):72-82.

Sun, Kun. 2018. Approaching The Double - Nominal Construction In Mandarin Chinese Through The Semantic - Cognitive Interaction. Studia Linguistica, 72(3), 687-724.

Sun, Kun. 2019a. The Integration Functions of Topic Chains in Chinese Discourse. Acta Linguistica Asiatica, 9(1), 29-57.

Sun, Kun. 2019b. Teaching English-Chinese textual translation strategies: A topic-chain approach. Babel, 65(2), 286-315.

Talmy, Leonard. 2000. Toward a Cognitive Semantics (II): Typology and Process in Concept Structuring. Cambridge: MIT Press.

Tao, Liang. 1993. Zero Anaphora in Chinese: Cognitive Strategies in Discourse Processing. Boulder: University of Colorado dissertation.

Tao, Liang. 1996. Topic discontinuity and zero anaphora in Chinese discourse: cognitive strategies in discourse processing. Studies in Anaphora, ed. by Barbara, Fox, 487-513. Amsterdam: John Benjamins.

Tao, Liang. 2001. Switch reference and zero anaphora: emergent reference in discourse processing. In Alan Cienki, Barbara J. Luka and Michael B. Smith (eds.), Conceptual and Discourse Factors in Linguistic Structure, 253-269. Stanford: CSLI Publications.

Tsao, Feng-Fu. 1977. A Functional Study of Topic in Chinese: the First Step toward Discourse Analysis. Log Angles: University of Southern California dissertation.

van Hoek, K. 1997. Anaphora and Conceptual Structure . Chicago: University of Chicago Press.

von Heusinger, K. 2007. Accessibility and definite noun phrases. Anaphors in Text, ed. by M. Schwarz-Friesl et al, 123-144. Amsterdam: John Benjamins.

Voloshin, V. I. 2009. Introduction to Graph and Hypergraph Theory. New York: Nova Science Publisher.

Wang. Hongjun. \& Li, Rong. 2014. Lun hanyu pianzhang de jiben danwei he liushuiju de Chenying [A study of the fundamental unit in Chinese discourse and the cause of forming flowing sentence]. Yuyanxue Luncong[Essays on Linguistics] 2014(48):11-40. Beijing: The Commercial Press.

Wilson, Robert.A. \& Keil, Frank.C. (Eds.) 1999. The MIT Encyclopedia of Cognitive Sciences. Cambridge, MA: MIT Press.

Xu, Yulong. 2004. Pianzhang Huizhi de Gongneng Yuyong Tansuo[An Explorations of Functional Pragmatics in Discourse Anaphora ]. Shanghai: Shanghai Foreign Languages Education Press.

You, Yuling. 1998. Interpreting Chinese Zero Anaphors within Topic Continuity. UrbanaChampaign: University of Illinois dissertation.

Zhan, Meilin. Lev, Roger. \& Kehler, Andrew. 2016. Bayesian pronoun interpretation in Mandarin Chinese. The Annual Meeting of the Cognitve Science, Philadelphia, August 10-13, 2016.( http://mindmodeling.org/cogsci2016/papers/0414/paper0414.pdf)

Zhu. Dexi. 1985. Yufa Wenda[Q\&A for Chinese Grammar]. Beijing: Commercial Press. 


\section{Appendix:}

Chinese Characters of Examples

[1] 舅舅來看我, 帶了份烤鴨, 很好吃。

[2] 他腳受傷了, 不能來聽講座了。

［3］李四這傢伙, 我因為救他, 受了傷, 竟然不來看我, 跑到紐約度假去了, 唉, 真倒楣, 受傷嚴重, 不能起床了 $\cdots$

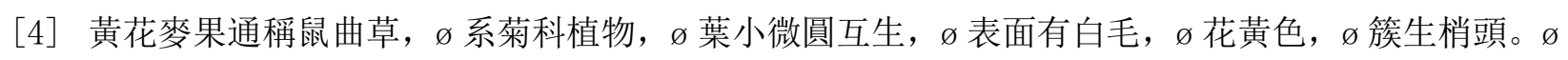
春天采嫩葉, $\varnothing$ 捣爛去汁, $\varnothing$ 和粉作糕, $\varnothing$ 稱黃花麥果糕。(周作人《故鄉的野草》)

[5] 一天, $\varnothing 1$ 趁他洗澡, 我 1 便去檢查他的衣服, $\varnothing 1$ 翻了上衣的每個口袋 $2, \varnothing 1$ 又去翻褲子的口袋 3 , $\varnothing 2 \& 3$ 結果既無現金, $\varnothing 2 \& 3$ 有無存摺。

[6] (a) 安徽省…...

(b) 澇災則以淮河流域較多,

(c) ø主要出現在 7-8 月,

(d) ø次為長江流域,

(e) ø多出現在 6-7 月。

７7（他們給他）抓了十幾劑湯藥，(金山）吃了果然不行, (他們) 便只好單一（給他）吃飯吃水，(金 山）上下兩個穴總算通暢, (食物排泄物) 進出無礙, (令他們) 苦惱的是和天白做了一類……（劉恒 《伏羲伏羲》)

[8] 金子仙 ${ }_{1}$ 心想, 自己真是碰上大好人。 $\varnothing_{1}$ 千恩萬謝之後， $\varnothing_{1}$ 便揣起方子快快活活去抓藥。Ø(金子仙? 俊二? 他們? ）回去按方一用, 凤（?）果見成效。這藥仿佛藏著神道, 不多天, 俊二的頭髮漸漸變黑 變亮, 凤仿佛用油煙墨一遍遍染上的。ø隨後就眼看著粗起來, 凤猶如春天的草枝。半月後, (他們) 忽 見每根頭髮都拱出烏黑嶄亮的尖子來，ø好像竄芽拔節，ø叫金家父女驚喜得直叫。(馮驥才《神鞭》)

[9] 新來的客人中, 有一位叫徐壯圖的中年男士, 是上海交通大學的畢業生; 生得品貌堂堂, 高高的個兒, 結實的身體, 穿著剪裁合度的西裝, 顯得分外英挺。(白先勇《永遠的尹雪䡴》)

[10]荣薺藏在爛泥裡。赤了腳, 在涼浸浸滑滑溜的泥裡踩著, 一一哎, 一個硬疮㽽! 伸手下去, 一個 紅紫紅紫的䒬薺。(汪曾祺《受戒》)

[11] 他們經常打牌。這是個打牌的好地方。把大殿上吃飯的方桌往門口一搭, 斜放著, 就是牌桌。 (汪曾祺《受戒》)

\section{Abbreviations and Symbols}

CA case maker

CL classifier

CONJ conjunction

$\mathrm{DE}$ pre-nominal modifier $(\mathrm{de}) /$ postverbal resulative marker $(D E)$

$e \quad$ empty category

DNC double nominal construction

M measure word
MA modality adverbs

(jiu, cai, you, hai et al

MOD modifier

NP noun phrase

PFV perfective aspect

PL plural form

PRT particle

PROV progressive 
